\title{
SENSITIVITY OF Venturia inaequalis CHILEAN ISOLATES TO DIFENOCONAZOLE, FENARIMOL, MANCOZEB, AND PYRIMETHANIL
}

\author{
Jose Luis Henríquez S. ${ }^{*}$, Oliver Sarmiento V. ${ }^{1}$, and Paula Alarcón C. ${ }^{1}$
}

\begin{abstract}
Apple scab (Venturia inaequalis) is the most important disease in Chilean apple (Malus domestica Borkh.) orchards where fungicide management is the main tool to control disease. Sensitivity tests to difenoconazole, fenarimol, mancozeb, and pyrimethanil fungicides were conducted on $V$. inaequalis wild isolates to construct local baseline sensitivity distributions, and compare them with a collection of isolates from seven different commercial orchards with no evidence of practical resistance. In vitro assays were conducted and sensitivity was measured as inhibition of mycelial growth (difenoconazole, fenarimol, pyrimethanil) or conidial germination (mancozeb). Departure from the baseline distribution to less sensitivity was found for difenoconazole, fenarimol, and mancozeb with resistance factors of 4.7, 5.8, and 2.1, respectively. The highest difference between baseline and orchard populations was observed for fenarimol which showed the highest shift to less sensitivity. Discriminatory doses of 0.04, 1.0, 0.6, and $0.2 \mu \mathrm{g} \mathrm{mL}^{-1}$ are proposed for in vitro monitoring of sensitivity to difenoconazole, fenarimol, mancozeb, and pyrimethanil, respectively.
\end{abstract}

Key words: Apple, apple scab, fungicides, DMI fungicides, dithiocarbamates, anilinopyrimidines.

\section{INTRODUCTION}

Apple scab incited by Venturia inaequalis (Cooke) Winter (anamorph Spilocaea pomi Fr.) is the most important disease in apples grown in Chile. Chemical control with fungicides has been the main tool to control disease and fungicides are sprayed when there are favorable conditions for disease development or at fixed intervals depending on the growing season, area of production, and climatic conditions. Failure to control disease has been observed in some orchards and fungicide resistance is claimed to be the main reason, although there is only one published study about fungicide resistance (Sallato and Latorre, 2006) reporting on resistance to strobilurin kresoxym methyl in southern Chile. There are some unpublished studies from the chemical industry testing the sensitivity of the pathogen's local isolates to commonly used fungicides. Data obtained are normally compared with standards found in the literature with data gathered from studies conducted elsewhere. There are no studies about the sensitivity of wild local isolates, and there is a

${ }^{1}$ Universidad de Chile, Facultad de Ciencias Agronómicas, Casilla 1004, Santiago, Chile. *Corresponding author (jhenriqu@uchile.cl). Received: 5 January 2010.

Accepted: 30 August 2010. lack of information on baseline sensitivities to some old and commonly used fungicides.

Fungicide resistance in $V$. inaequalis is well documented worldwide for old fungicides such as dodine (Köller et al., 1999; Broniarek-Niemiec and Bielenin, 2008), benzimidazole (Koenraadt et al., 1992), demethylation inhibitors (DMIs) (Sholberg and Haag, 1993; Köller et al., 1997), and newer fungicides such as strobilurins (Olaya and Koller, 1999; Fontaine et al., 2009) and anilinopyrimidines (Küng et al., 1999). There are no reports in the literature about sensitivity to mancozeb, an old fungicide still used for apple scab control, used alone or mixed mainly with DMIs as an anti-resistance strategy. The objectives of this research were to determine the sensitivity of wild Chilean populations to the difenoconazole, fenarimol, mancozeb, and pyrimethanil fungicides, and to compare them with the sensitivity of isolates obtained from commercial orchards under conventional fungicide management.

\section{MATERIALS AND METHODS}

\section{Fungal isolates}

Venturia inaequalis wild isolates were obtained from apple trees located far away from commercial orchards 
having no history of fungicide treatments from central to southern Chile in 2007 and 2008. Isolates from seven commercial orchards, with a long history of fungicide treatments, were collected in central and southern Chile in 2008 and 2009. These orchards had low levels of apple scab and failure to control disease was not observed.

\section{Monoconidial cultures}

Individual scab lesions on apple leaves were washed with $100 \mu \mathrm{L}$ sterile distilled water (SDW), put in water agar medium, and incubated at $20 \pm 1{ }^{\circ} \mathrm{C}$. After 18 to $24 \mathrm{~h}$, single germinating $V$. inaequalis conidia were transferred to acidified potato dextrose agar (aPDA) plates $(0.5 \mathrm{~mL}$ lactic acid per liter of medium). A culture was collected and monoconidial isolates replicated to obtain enough fungal material to conduct sensitivity tests. A total of 50 wild isolates and 50 orchard isolates were tested for each fungicide since a higher number does not increase test precision (Smith et al., 1991).

\section{Fungicides}

Commercial formulations were employed for sensitivity assays; difenoconazole (Score 250 EC, Syngenta, Basel, Switzerland), fenarimol (Rubigan 12 EC, Gowan, Yuma, Arizona, USA), mancozeb (Dithane M 45 WP, Dow Agro Science, Indianapolis, Indiana, USA), and pyrimethanil (Scala 400 SC, Bayer Crop Science, Leverkussen, Germany).

\section{Sensitivity assays}

Venturia inaequalis sensitivity to mancozeb was determined according to a previously described procedure (Köller et al., 1999) in brief conidial suspensions in SDW obtained from 4 to $6 \mathrm{wk}$ old monoconidial cultures where 30 to $50 \mu \mathrm{L}$ were spread on aPDA amended with the tested fungicide in concentrations ranging from 0 to $10 \mu \mathrm{g}$ $\mathrm{mL}^{-1}$ and incubated for $24 \mathrm{~h}$. Germination of 100 conidia was assessed in four replicate plates for each fungicide concentration. A conidium was considered germinated when its germinating tube was at least 1.5 times its own length.

Venturia inaequalis to difenoconazole and fenarimol, two DMI fungicides, was determined for mycelial growth on aPDA amended with the respective fungicide in concentrations ranging from 0 to $10 \mu \mathrm{g} \mathrm{mL}^{-1}$ in four replicate plates. A small piece of mycelium, about $1 \mathrm{~mm}$ in diameter, was transferred from monoconidial cultures to fungicide amended plates and four different isolates were placed in a Petri dish. The mean colony diameter was measured after 4 wk of incubation at $20 \pm 1{ }^{\circ} \mathrm{C}$. Sensitivity to pyrimethanil was determined for the inhibition of mycelial growth in a synthetic medium consisting of 10 g glucose; $1.5 \mathrm{~g} \mathrm{~K}_{2} \mathrm{HPO}_{4}, 2 \mathrm{~g} \mathrm{KH}_{2} \mathrm{PO}_{4}, 1 \mathrm{~g}\left(\mathrm{NH}_{4}\right)_{2} \mathrm{SO}_{4}$,
$0.5 \mathrm{~g} \mathrm{MgSO} 4 * 7 \mathrm{H}_{2} \mathrm{O}$, and $12.5 \mathrm{~g}$ agar per liter of medium (SDW) (Leroux et al., 1999).

The effective concentration to inhibit mycelial growth or conidial germination by $50 \%\left(\mathrm{ED}_{50}\right)$ was estimated by performing a regression between the percentage of mycelial growth inhibition or conidial germination against the fungicide concentration logarithm. Values of the $\mathrm{ED}_{50}$ frequency distribution were used to construct population sensitivity curves. $\mathrm{ED}_{50}$ values from wild and orchard isolates were log transformed and analyzed by the Kolmogorov and Smirnov normality test (Lilliefors, 1967). Mean wild and orchard population sensitivities were subjected to ANOVA (Minitab, State College, Pennsylvania, USA). Discriminatory doses to separate sensitive from resistant isolates were proposed based on wild sensitivities according to Köller et al. (1991). Resistance factors (RF) were calculated for each fungicide as the ratio between mean sensitivity of the orchard population divided by the mean sensitivity of the wild population (Kunz et al., 1997).

\section{RESULTS AND DISCUSSION}

Distribution of sensitivities of wild and orchard populations were single lognormal according to the Kolmogorov and Smirnov test for difenoconazole $(\mathrm{p}=$ 0.12 and $p>0.15)$; fenarimol $(p=0.05$ and $p>0.10)$; mancozeb $(p>0.15)$; and pyrimethanil $(p=0.08$ and $p>$ $0.15)$, respectively.

Baseline sensitivity to difenoconazole of the wild population ranged from 0.00001 to $2.9 \mu \mathrm{g} \mathrm{mL}^{-1}$ resulting in a separation factor of 290000 (ratio between the least and most sensitive isolate of the population) (Table 1). A tenfold amplitude decrease in the separation factor was observed for the orchard population which fluctuated from 0.0002 to $5.8 \mu \mathrm{g} \mathrm{mL}^{-1}$ (Table 2), reflecting the loss of the most sensitive isolates and the presence of new and less sensitive isolates absent in the wild population. Accordingly, the sensitivity distribution curve of the orchard population has been displaced to the right (Figure 1), reaching a mean sensitivity of $0.08 \mu \mathrm{g} \mathrm{mL}^{-1}$ significantly different from the baseline sensitivity of $0.017 \mu \mathrm{g} \mathrm{mL}^{-1}(\mathrm{p}=0.002)$. The wild isolates showed a high sensitivity to difenoconazole and reflected a great intrinsic activity of this fungicide when compared to fenarimol's lower activity. Similar results were obtained by Kunz et al. (1997) when assessing the sensitivity of in vivo DMIs where difenoconazole was ranked as the most active fungicide against $V$. inaequalis when compared to flusilazol, fenarimol, tebuconazole, and pyrifenox.

Difenoconazole has been used for more than a decade to control apple scab in Chile and it is the latest DMI fungicide introduced to control it. It is regarded as one 
Table 1. Sensitivity distribution $\left(E D_{50}\right)$ of wild and orchard populations of Venturia inaequalis to tested fungicides.

\begin{tabular}{lccc}
\hline Fungicides & Range $\mathbf{E D}_{\mathbf{5 0}}$ & Mean $\mathbf{E D}_{\mathbf{5 0}}$ & DD \\
\cline { 2 - 4 } & & $\mu \mathrm{g} \mathrm{mL}^{-1}$ & \\
Difenoconazole & $0.00001-2.9$ & Wild population & 0.04 \\
Fenarimol & $0.0003-1.4$ & 0.017 & 1.0 \\
Mancozeb & $0.046-6.5$ & 0.09 & 0.6 \\
Pyrimethanil & $0.0037-2.3$ & 0.44 & 0.2 \\
& & 0.10 & \\
Difenoconazole & & & Resistance Factor \\
Fenarimol & $0.0002-5.8$ & 0.08 & 4.7 \\
Mancozeb & $0.0048-5.1$ & 0.53 & 5.8 \\
Pyrimethanil & $0.0046-20.0$ & 0.93 & 2.1 \\
\hline EDjorcial orchard population & 0.14 & 1.4
\end{tabular}

$\mathrm{ED}_{50}$ : The effective concentration to inhibit mycelial growth or conidial germination by $50 \%$.

DD: Discriminatory dose proposed in this study.

Resistance factor: Mean $\mathrm{ED}_{50}$ of the orchard population divided by mean $\mathrm{ED}_{50}$ of wild population.

of the most effective fungicides which is widely used alone or mixed with a multisite fungicide as a resistance management strategy (Köller and Wilcox, 1999; 2000). Our results showed that orchard populations have lost sensitivity to difenoconazole, but there is still a proportion of sensitive isolates. This is considered to be a good situation compared with narrow sensitivity distributions where fungicide resistance can be acquired faster (Köller et al., 1991). Nevertheless, an RF value of 4.7 was calculated for this fungicide, thus indicating a possible decrease in field activity. Smith et al. (1991) reported loss of field activity of DMI fungicides with RF values over 3 . According to baseline sensitivity, a concentration of 0.04 $\mu \mathrm{g} \mathrm{mL}^{-1}$ is proposed as a discriminatory dose for in vitro monitoring of sensitivity to difenoconazole.

Sensitivity of the wild population to fenarimol ranged from 0.0003 to $1.4 \mu \mathrm{g} \mathrm{mL}^{-1}$ with a separation factor of 4667 and a mean sensitivity value of $0.09 \mu \mathrm{g} \mathrm{mL}^{-1}$ (Table 1). The sensitivity of the orchard population was narrowed down to a separation factor of 1062, thus reflecting the loss of the most sensitive part of the population and an increase of less sensitive isolates. A great departure from the baseline population was observed for fenarimol when compared to difenoconazole (Figure 1), and where a larger part of the population was to the right. Accordingly, a higher resistance factor $(\mathrm{RF}=5.8)$ was calculated. Mean sensitivity values of the wild and orchard populations were significantly different $(\mathrm{p}=0.001)$. The wild population showed a wide spectrum of sensitivities to fenarimol as expressed by the separation factor of 4667, which is greater than the value of 60 previously reported for this fungicide (Köller et al., 1991).

This data reflects important differences in fenarimol sensitivity of Chilean isolates and populations from elsewhere. Fiaccadori et al. (1987) reported a mean $\mathrm{ED}_{50}$ of $0.04 \mu \mathrm{g} \mathrm{mL}^{-1}$ for fenarimol in unexposed isolates from Italy and Holland, whereas the same value was obtained by Köller et al. (1991) for New York isolates, while Thind et al. (1986) obtained a mean $\mathrm{ED}_{50}$ of $0.03 \mu \mathrm{g} \mathrm{mL}^{-1}$. Accordingly, our results of a discriminatory dose of $1.0 \mu \mathrm{g} \mathrm{mL}^{-1}$ is suggested for the in vitro determination of sensitivity to fenarimol, which is higher than the $0.05 \mu \mathrm{g} \mathrm{mL}^{-1}$ reported by Köller et al. (1991) and Smith et al. (1991). Therefore, the use of discriminatory doses obtained in foreign studies for testing in vitro sensitivity of Chilean isolates to fenarimol would be misleading.

Baseline sensitivity to mancozeb varied from 0.046 to $6.5 \mu \mathrm{g} \mathrm{mL}^{-1}$ (Table 1) representing a separation factor of 141, while the orchard population had a separation factor greater than 2000 with sensitivity values varying from 0.0046 to $20 \mu \mathrm{g} \mathrm{mL}^{-1}$ (Table 2). A wider distribution of sensitivities observed in the orchard population for this fungicide resulted from the occurrence of few highly sensitive isolates not present in the baseline population studied, as well as the increase of new and less sensitive isolates (Figure 1). The mean sensitivity of the wild $(0.44 \mu \mathrm{g}$ $\left.\mathrm{mL}^{-1}\right)$ and orchard $\left(0.93 \mu \mathrm{g} \mathrm{mL}^{-1}\right)(\mathrm{p}=0.001)$ populations were significantly different and RF was calculated as 2.1. Orchard isolates, 2 to 4 times less sensitive to the fungicide dodine, were related to failure to control apple scab (McHardy, 1996). Both dodine and mancozeb are multisite fungicides and similar shifting of sensitivity from baseline populations could be expected in orchard populations. Mancozeb is an old fungicide widely used to control apple scab and still mainly employed mixed 

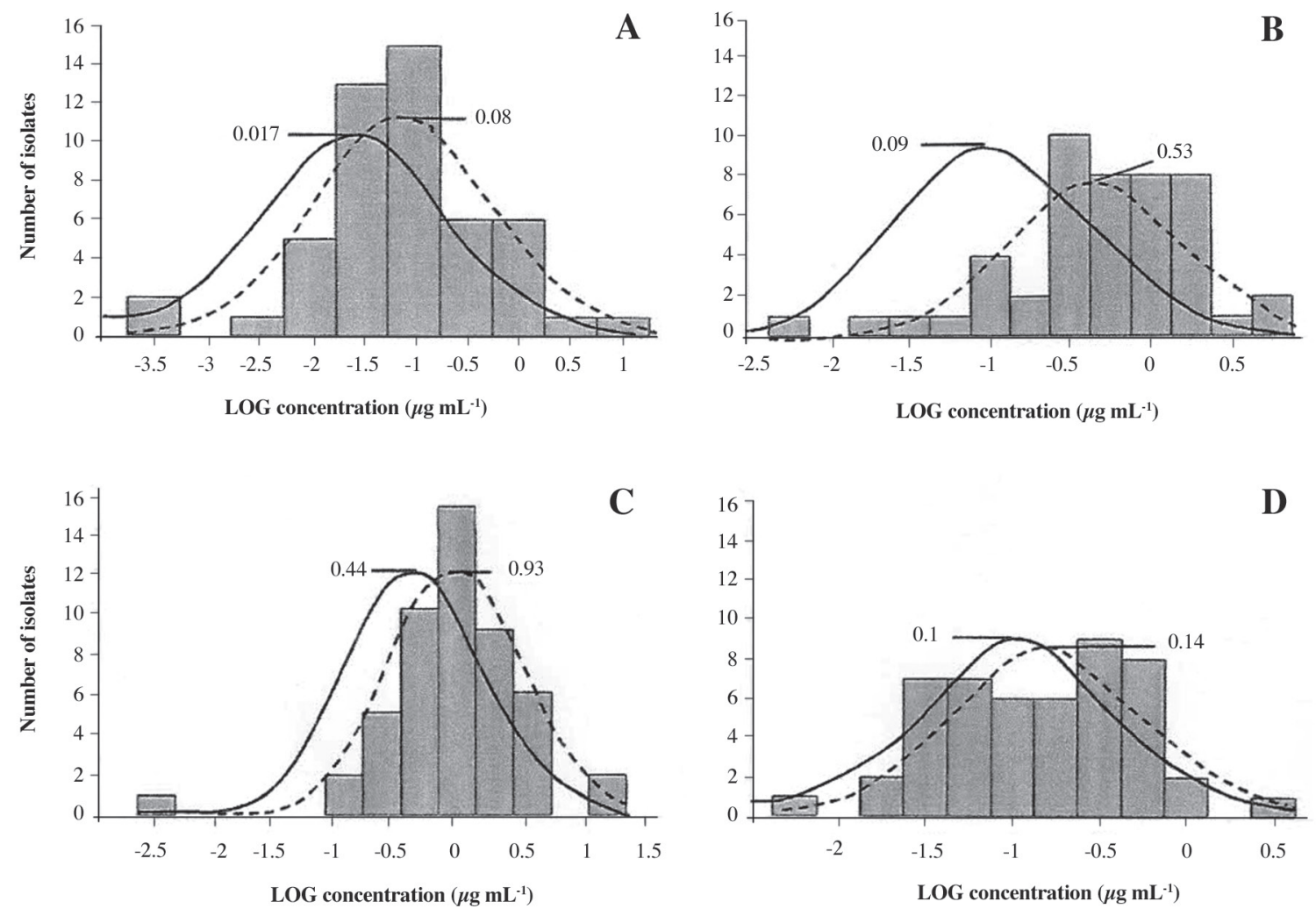

$\mathrm{ED}_{50}$ : The effective concentration to inhibit mycelial growth or conidial germination by $50 \%$.

Figure 1. Sensitivity frequency distribution of Venturia inaequalis orchard isolates to tested fungicides and mean $\mathrm{ED}_{50}$ (discontinuous line) compared to baseline sensitivity and mean $\mathrm{ED}_{50}$ (continuous line). A. Difenoconazole; B. Fenarimol; C. Mancozeb; D. Pyrimethanil.

with more specific fungicides as an anti-resistance strategy. Very little difference was observed among baseline and orchard populations, which could be the result of a lower resistance pressure or the intrinsic lesser likelihood of building up resistance due to its multisite mode of action. A concentration of $0.6 \mu \mathrm{g} \mathrm{mL}^{-1}$ is proposed as a discriminatory dose for in vitro determination of sensitivity to mancozeb.

Sensitivity of the baseline population to pyrimethanil was narrow and fluctuated from 0.0037 to $2.3 \mu \mathrm{g} \mathrm{mL}^{-1}$ with a separation factor of 621 (Table 1). Narrower distributions were described by Köller et al. (2005) in a sensitivity study of 22 isolates from New York which could result from the small number of tested isolates. A very similar distribution of sensitivities was observed in this study for the orchard population which ranged from 0.0061 to $3.2 \mu \mathrm{g} \mathrm{mL}^{-1}$ with a separation factor of 524 (Table 2 , Figure 1). The differences in mean sensitivity values of wild and orchard populations which were not significant ( $p=0.26)$ and an RF value of 1.4 indicate that sensitivity of $V$. inaequalis orchard isolates to pyrimethanil has not

Table 2. Distribution of sensitives $\mathrm{ED}_{50}\left(\mu \mathrm{g} \mathrm{mL}^{-1}\right)$ of orchard population of Venturia inaequalis to the fungicides tested.

\begin{tabular}{|c|c|c|c|}
\hline & $\begin{array}{l}\text { ED } \\
\text { Range }\end{array}$ & $\begin{array}{l}\text { Mean } \\
\text { ED }_{50}\end{array}$ & $\begin{array}{c}\text { Resistance } \\
\text { factor }^{1}\end{array}$ \\
\hline Difenoconazole & $0.0002-5.8$ & 0.08 & 4.7 \\
\hline Fenarimol & $0.00048-5.1$ & 0.53 & 5.8 \\
\hline Mancozeb & $0.0046-20.0$ & 0.93 & 2.1 \\
\hline Pyrimehanil & $0.0061-3.2$ & 0.14 & 1.4 \\
\hline
\end{tabular}

${ }^{1}$ Mean $\mathrm{ED}_{50}$ of the orchard population divided by the mean $\mathrm{ED}_{50}$ of the wild type population.

$\mathrm{ED}_{50}$ : The effective concentration to inhibit mycelia growth or conidial germination by $50 \%$. 
significantly moved from the baseline. A discriminatory dose of $0.2 \mu \mathrm{g} \mathrm{mL}^{-1}$ is suggested for in vitro determination of sensitivity to pyrimethanil. The same dose was determined by Köller et al. (2005) for the New York isolates.

\section{CONCLUSIONS}

A departure from the baseline population of $V$. inaequalis isolates from commercial orchards was demonstrated for the first time for difenoconazole, fenarimol, and mancozeb in Chile. The departure from baseline sensitivity for fenarimol was considerably higher than for difenoconazol. Fenarimol exhibited the highest RF among the tested fungicides. The presence of isolates highly sensitive to fungicides tested in orchard populations indicates a slow process of sensitivity loss, and if adequate resistance management is undertaken, resistance to the studied fungicides will be delayed. It is important to note that the loss of sensitivity to pyrimethanil of orchard populations was not found, thus subsequent monitoring and appropriate anti-resistance management would delay acquisition of resistance. The results presented are representative of a region, not of particular orchards with failure to control apple scab, and specific situations should be analyzed in detail to better understand the local response of $V$. inaequalis isolates to fungicides used to control it.

\section{ACNOWLEDGEMENTS}

The study was funded by a by the FONDECYT 11060453 grant.

\section{RESUMEN}

Sensibilidad de aislados chilenos de Venturia inaequalis a difenoconazole, fenarimol, mancozeb y pyrimethanil. La sarna del manzano (Venturia inaequalis) es la principal enfermedad del cultivo en Chile y es controlada principalmente con el uso de fungicidas. Se realizaron pruebas de sensibilidad a los fungicidas difenoconazole, fenarimol, mancozeb y pyrimethanil en aislados monoconidiales de cepas silvestres de $V$. inaequalis con el fin de elaborar curvas basales de sensibilidad y compararlas con la sensibilidad de una colección de aislados monoconidiales provenientes de siete huertos comerciales sin evidencias de resistencia práctica. Se realizaron pruebas in vitro donde la sensibilidad se midió como la inhibición del crecimiento miceliar (difenoconazole, fenarimol y pyrimethanil) o la inhibición de la germinación de conidias (mancozeb). La población de huertos comerciales estudiada presentó una menor sensibilidad a los fungicidas difenoconazole, fenarimol y mancozeb con valores de factor de resistencia 4,$7 ; 5,8 ;$ y 2,1 para difenoconazole, fenarimol y mancozeb, respectivamente. La mayor diferencia de sensibilidad entre la población silvestre y la de huerto se obtuvo con feranimol, fungicida para el cual se observó el mayor cambio hacia una menor sensibilidad. Se proponen dosis discriminatorias de 0,$04 ; 1,0 ; 0,6$; y $0,2 \mu \mathrm{g} \mathrm{mL}^{-1}$ para difenoconazole, fenarimol, mancozeb y pyrimethanil, respectivamente.

Palabras clave: manzano, sarna del manzano, fungicidas, fungicidas IBE, ditiocarbamatos, anilinopirimidinas.

\section{LITERATURE CITED}

Broniarek-Niemiec, A., and A. Bielenin. 2008. Resistance of Venturia inaequalis to strobilurin and dodine fungicides in Polish apple orchards. Zemdirbyste Agriculture 95:366-372.

Fiaccadori, R., A.J. Gielink, and J. Dekker. 1987. Sensitivity to inhibitors of sterol biosynthesis in isolates of Venturia inaequalis from Italian and Dutch orchards. Netherland Journal of Plant Pathology 93:285-287.

Fontaine, S., F. Remuson, L. Fraissinet-Tachet, A. Micoud, R. Marmeisse, and D. Melayah. 2009. Monitoring of Venturia inaequalis harbouring the QoI resistance G143A mutation in French orchards as revealed by PCR assays. Pest Management Science 65:74-81.

Koenraadt, H., S. Somerville, and A.L. Jones. 1992. Characterization of mutations in the Beta-tubulin gene of benomyl-resistant field strains of Venturia inaequalis and other plant pathogenic fungi. Phytopathology 82:1348-1354.

Köller, W., D.M. Parker, and K.L. Reynolds. 1991. Baseline sensitivities of Venturia inaequalis to sterol demethylation inhibitors. Plant Disease 75:726-728.

Köller, W., and W.F. Wilcox. 1999. Evaluation of tactics for managing resistance of Venturia inaequalis to sterol demethylation inhibitors. Plant Disease 83:857863.

Köller, W., and W.F. Wilcox. 2000. Interactive effects of dodine and the DMI fungicide fenarimol in the control of apple scab. Plant Disease 84:863-870.

Köller, W., W.F. Wilcox, J. Barnard, and A.L. Jones. 1997. detection and quantification of resistance of Venturia inaequalis populations to sterol demethylation inhibitors. Phytopathology 87:184-190.

Köller, W., W.F. Wilcox, and A.L. Jones. 1999. Quantification, persistence, and status of dodine resistance in New York and Michigan orchard populations of Venturia inaequalis. Plant Disease 83:66-70. 
Köller, W., W.F. Wilcox, and D.M. Parker. 2005. Sensitivity of Venturia inaequalis populations to anilinopyrimidine fungicides and their contribution to scab management in New York. Plant Disease 89:357365.

Küng, R., K.M. Chin, and U. Gisi. 1999. Sensitivity of Venturia Inaequalis to cyprodinil. p. 313-322. In Lyr, H., P.E. Russel, H.W. Dehne, and H.D. Sisler (eds.) Modern fungicides and antifungal compounds II. Intercept, Andover, UK.

Kunz, S., H. Deising, and K. Mendgen. 1997. Acquisition of resistance to sterol demethylation inhibitors by populations of Venturia inaequalis. Phytopathology 87:1272-1278.

Leroux, P., F. Chapeland, D. Debrosses, and M. Gredt. 1999. Patterns of cross-resistance to resistance to fungicides in Botryotinia fuckeliana (Botrytis cinerea) isolated from French vineyards. Crop Protection 18:687-697.

Liliefors, H.W. 1967. On the Kolmogorov-Smirnov test for normality with mean and variance unknown. Journal of the American Statistical Association 318:399-402.
McHardy, W.E. 1996. Apple scab: Biology, epidemiology and management. 545 p. APS Press, The American Phytopathological Society, St Paul, Minnesota, USA.

Olaya, G., and W. Köller. 1999. Baseline sensitivities of Venturia inaequalis to the strobilurin kresoxymmethyl. Plant Disease 83:274-278.

Sallato, B., and B. Latorre. 2006. First report of practical resistance to QoI fungicides in Venturia inaequalis (apple scab) in Chile. Plant Disease 90:375.

Sholberg, P.L., and P.D. Haag. 1993. Sensitivity of Venturia inaequalis isolates from British Columbia to flusilazole and myclobutanil. Canadian Journal of Plant Pathology 15:102-106.

Smith, F.D., D.M. Parker, and W. Koller. 1991. Sensitivity distribution of Venturia inaequalis to the sterol demethylation inhibitor flusilazole: Baseline sensitivity and implication for resistance monitoring. Phytopathology 81:392-396.

Thind, T.S., M. Clerjeu, and J.M. Olivier. 1986. First observation on resistance in Venturia inaequalis and Guignardia bidwellii to ergosterol biosynthesis inhibitors in France. British Crop Protection Conference 2:491-498. 